\title{
Effects of Organic Soil Amendments on Photosynthetic Traits of Black Pepper (Piper nigrum L.) in an Alluvial Soil
}

\author{
Kevin Muyang Tawie Sulok $\mathbb{D}^{1},{ }^{1}$ Osumanu Haruna Ahmed, ${ }^{2,3,4}$ Choy Yuen Khew, ${ }^{1}$ \\ Pei Sing Lai, ${ }^{1}$ Jarroop Augustine Mercer Zehnder, ${ }^{1}$ and Mohd Effendi Wasli ${ }^{5}$ \\ ${ }^{1}$ Research and Development Division, Malaysian Pepper Board, Kuching 93916, Sarawak, Malaysia \\ ${ }^{2}$ Department of Crop Science, Faculty of Agriculture and Food Sciences, Universiti Putra Malaysia (UPM), Bintulu Campus, \\ Bintulu 97008, Sarawak, Malaysia \\ ${ }^{3}$ Institute of Tropical Agriculture and Food Security (ITAFoS), Universiti Putra Malaysia (UPM), Serdang 43400, \\ Selangor, Malaysia \\ ${ }^{4}$ Institute of Ekosains Borneo, Universiti Putra Malaysia (UPM), Bintulu Campus, Bintulu 97008, Sarawak, Malaysia \\ ${ }^{5}$ Faculty of Resource Science and Technology, Universiti Malaysia Sarawak, Kota Samarahan 94300, Sarawak, Malaysia
}

Correspondence should be addressed to Kevin Muyang Tawie Sulok; kevinmuyang@mpb.gov.my

Received 8 September 2020; Revised 25 November 2020; Accepted 30 November 2020; Published 16 December 2020

Academic Editor: Claudio Cocozza

Copyright (c) 2020 Kevin Muyang Tawie Sulok et al. This is an open access article distributed under the Creative Commons Attribution License, which permits unrestricted use, distribution, and reproduction in any medium, provided the original work is properly cited.

\begin{abstract}
Black pepper in Sarawak, Malaysia, is mainly cultivated using the conventional method involving heavy usage of chemical compound fertilizers. Organic soil amendments can reduce the required amounts of chemical fertilizers. So, the objectives of this study were to compare selected properties of soils as well as the physiological performances of mature vines following the application of fermented juices, biochar, and compost. There were five treatments; each replicated five times in a randomized complete block design. Treatments were as follows: (i) FNPK-NPK $15: 15: 15$ compound fertilizer; (ii) FPJ (fermented plant juice); (iii) FPJBC (FPJ, biochar, and compost); (iv) FFJ (fermented fruit juice); and (v) FFJBC (FFJ, biochar, and compost). The results revealed that combined fermented juices, biochar, and compost positively improved soil bulk density, soil porosity, TOC, C/N ratio, available $\mathrm{P}$, exchangeable $\mathrm{K}$, and exchangeable $\mathrm{Ca}$. The fermented juices incorporated with biochar and compost had favourable effects on the leaf chlorophyll concentration, Normalized Difference Vegetation Index (NDVI), and gas exchange rates such as photosynthesis, stomatal conductance, and transpiration. Pepper leaf chlorophyll, NDVI, and photosynthesis rate were negatively correlated with soil total $\mathrm{N}$. These results suggested that introducing organic soil amendments such as fermented juices, biochar, and compost improved soil physiochemical properties and black pepper physiological traits.
\end{abstract}

\section{Introduction}

In black pepper cultivation, a healthy and vigorously grown vine is characterized by fully developed canopy which wholly covers the pole which supports it. As pepper is a nutrient demanding plant especially the mature vines, adequate nutrition to ensure plant health and flower initiation is essential $[1,2]$. Managing mature pepper vines require a different form of farming practices including fertilization programmes. Paulus [3] mentioned that fertilization of mature vines is done at the onset of the rainy season to induce flowering. There is usually no further application of granular compound fertilizer from January to June (berry filling stage right to harvesting). In Sarawak, pepper vines are mainly fertilized using chemical fertilizers. The existing formulations for mature pepper vines are $12: 12: 17: 2+\mathrm{TE}$ and $14: 14: 21: 2+\mathrm{TE}$ [3]. Paulus and Anyi [3] calculated that approximately $1.5 \mathrm{~kg} /$ vine/year or three tonnes/hectare/year of $12: 12: 17: 2+\mathrm{TE}$ fertilizer is needed to fertilize mature vines in four splits, that is, $40 \%$, $30 \%, 20 \%$, and $10 \%$ at a monthly interval, right from the onset of the rainy season. Nevertheless, it has been shown that the addition of organic matters or amendments can significantly 
reduce the chemical fertilizers demand in many cultivation crops [4-6].

Due to the continuous application of inorganic chemical fertilizers, most pepper vineyards in Malaysia experienced degradation of soil health or quality [3]. Gradually, the infertile soil will reduce the yield and economic life of pepper vines. Developing organic farming through the use of organic amendments in the soil is of fundamental importance for sustainable ecosystem functioning $[5,7]$. Organic soil amendments such as fermented juices, biochar, and compost can improve and sustain soil health and quality. Organic farming is a production system that avoids or largely excludes the use of inorganic fertilizers and pesticides [8]. Besides, introducing organic farming in pepper cultivation is part of a current effort to tackle problems associated with low pepper prices by promoting a lower production cost and a cleaner environment. Physiological traits such as photosynthetic rates are a deciding factor for plant growth and yield development as optimum photosynthesis contributes to higher crop productivity, and it is the most basic and essential physiological process directly associated with pepper yield, particularly at mature fruiting developmental stages [3]. In addition, Kho and Chen [9] reported that plant yield potential can be significantly improved by increasing photosynthetic rates as it is closely related to the yield. This study focuses on mature pepper under organic soil amendments and related soil and plant responses.

\section{Materials and Methods}

2.1. Study Site and Experimental Soil. The soil at the planting site was previously surveyed by the Department of Agriculture, Soil Branch, Kuching, Sarawak, and it was named Bemang series [10]. Bemang series is an alluvial soil: fine loamy/silty, siliceous/mixed, acid, isohyperthermic, Typic Dystruptes, and alluvium from sedimentary rocks [11]. The $\mathrm{pH}$ of the experimental site was 4.87 . The study plot was a four-year-old mature pepper farm with a size of approximately 0.5 hectares. Mature P. nigrum var. Kuching vines as the most common variety in Malaysia were selected. To avoid significant variation in the data, only vines planted on flat land to gentle slope of not more than $10^{\circ}$ steepness were selected. Pepper vines planted using standard farm practice developed by the Malaysian Pepper Board (MPB) were used in this study. The study started in July 2016 and ended in February 2019.

2.2. Experimental Design and Treatments. The experiment was a randomized complete block design (RCBD) with five treatments and five replications giving a total of 25 vines per plot. Three plots were set up for this study. Figure 1 shows the experimental design of this study. The treatments (Table 1) were as follows: (i) TNPK - 12:12:17 fertilizer as control, (ii) FPJ (fermented plant juice), (iii) FPJBC (fermented plant juice incorporated with biochar and compost), (iv) FFJ (fermented fruit juice), and (v) FFJBC (fermented fruit juice incorporated with biochar and compost). The FPJ and FFJ were prepared every month to ensure only fresh

\begin{tabular}{|c|c|c|c|c|c|}
\hline FNPK1 & FNPK2 & FNPK3 & FFJ1 & FFJ2 & FFJ3 \\
\hline FNPK4 & FNPK5 & & FFJ4 & FFJ5 & \\
\hline \multicolumn{3}{|c|}{ Treatment 1 (FNPK) } & \multicolumn{3}{|c|}{ Treatment 4 (FFJ) } \\
\hline FPJ1 & FPJ2 & FPJ3 & FFJBC1 & FFJBC2 & FFJBC3 \\
\hline FPJ4 & FPJ5 & & FFJBC4 & FFJBC5 & \\
\hline \multicolumn{3}{|c|}{ Treatment 2 (FPJ) } & \multicolumn{3}{|c|}{ Treatment 5 (FFJBC) } \\
\hline FPJBC1 & FPJBC2 & FPJBC3 & & & \\
\hline FPJBC4 & FPJBC5 & & & & \\
\hline \multicolumn{3}{|c|}{ Treatment 3 (FPJBC) } & & & \\
\hline
\end{tabular}

Figure 1: Experimental design with randomized treatments in blocks.

batches of fermented juices were applied to the soils. From the onset of the experiment, FPJ and FFJ were applied once a month.

\subsection{Chemical Compound Fertilizer (12:12:17) Application.} For mature vines, granulated compound fertilizer was applied in a circular band just below the outer canopy of the vine, but avoiding the part where the main underground stem was. The fertilizer was placed in a shallow trench made using a rake and then covered over with a thin layer of soil. Frequency and rate of fertilizer application are shown in Table 2.

2.4. Fermented Plant Juice Application. The FPJ concoction was produced monthly according to the method by Zamora and Calub [13]. For the application that covers 100 mature pepper vines, $200 \mathrm{~mL}$ of FPJ was mixed in 16 litres of water. The mixture was sprayed directly onto the mounded area of the soil until the soil was relatively moistened. The FPJ was applied early in the morning or late evening to ensure the effectiveness of FPJ was intact.

2.5. Fermented Fruit Juice Application. The FFJ concoction was produced monthly according to the method by Zamora and Calub [13]. Approximately $200 \mathrm{~mL}$ of FFJ was mixed in 16 litres of water. The mixture was sprayed directly to the mounded area of the soil until the soil was relatively moistened. The FPJ was applied early in the morning or late evening to ensure the effectiveness of FPJ was intact.

2.6. Biochar Application. Following the method of Wahi et al. [14], the palm kernel shell (PK) biochar was produced. The PK biochar was applied to the soil before spraying fermented juices [13]. Approximately, $1 \mathrm{~kg}$ of PK biochar was broadcast on top of the mounded area of the soil. The soils were then loosened and mixed together with PK 
TABLE 1: Soil amendments description, composition, and rate of application for mature pepper vines.

\begin{tabular}{|c|c|c|c|c|}
\hline Treatment & Description & Composition & Rate of application & $\begin{array}{l}\text { Adapted } \\
\text { from }\end{array}$ \\
\hline FNPK & Control & NPK $12: 12: 17$ chemical compound fertilizer & $\begin{array}{l}\text { Standard recommended rate } \\
\text { (Table 2) }\end{array}$ & {$[12]$} \\
\hline FPJ & Fermented Plant Juice (FPJ) & $\begin{array}{c}1 \mathrm{~kg} \text { of leafy vegetables such as water spinach, } \\
\text { Chinese mustard, black pepper leaves, tapioca } \\
\text { leaves mixed with } 1 \mathrm{~kg} \text { molasses }\end{array}$ & $\begin{array}{l}200 \mathrm{~mL} \text { of FPJ in } 16 \text { litres of } \\
\text { water per month for } 100 \\
\text { vines }\end{array}$ & {$[13]$} \\
\hline FPJBC & $\begin{array}{l}\text { Fermented Plant Juice } \\
\text { incorporated with biochar and } \\
\text { compost (FPBC) }\end{array}$ & FPJ plus biochar and compost & $\begin{array}{c}200 \mathrm{~mL} \text { of FPJ in } 16 \text { litres of } \\
\text { water per month for } 100 \\
\text { vines } \\
2 \mathrm{~kg} \text { of biochar applied per } \\
\text { vine per year } \\
3.5 \mathrm{~kg} \text { compost applied per } \\
\text { vine for every } 3 \text { months }\end{array}$ & {$[12,13]$} \\
\hline FFJ & Fermented Fruit Juice (FFJ) & $\begin{array}{l}1 \mathrm{~kg} \text { of fruits such as banana, papaya, pumpkin, } \\
\text { and pepper berries mixed with } 1 \mathrm{~kg} \text { molasses }\end{array}$ & $\begin{array}{l}200 \mathrm{~mL} \text { of FFJ in } 16 \text { litres of } \\
\text { water per month for } 100 \\
\text { vines }\end{array}$ & [13] \\
\hline FFJBC & $\begin{array}{l}\text { Fermented Fruit Juice } \\
\text { incorporated with biochar and } \\
\text { compost (FFJBC) }\end{array}$ & FFJ plus biochar and compost & $\begin{array}{c}200 \mathrm{~mL} \text { of FFJ in } 16 \text { litres of } \\
\text { water per month for } 100 \\
\text { vines } \\
2 \mathrm{~kg} \text { of biochar applied per } \\
\text { vine per year } \\
3.5 \mathrm{~kg} \text { compost applied per } \\
\text { vine for every } 3 \text { months }\end{array}$ & {$[12,13]$} \\
\hline
\end{tabular}

TABLe 2: Rate of compound chemical fertilizer application for mature vines $[3,12]$.

\begin{tabular}{lcc}
\hline Month after planting & Compound chemical fertilizer & Quantity per vine (g) \\
\hline September & $12: 12: 17: 2+\mathrm{TE}$ & 500 \\
October & $12: 12: 17: 2+\mathrm{TE}$ & 500 \\
November & $12: 12: 17: 2+\mathrm{TE}$ & 250 \\
December & $12: 12: 17: 2+\mathrm{TE}$ & 250 \\
Total third year and above & & $=1500 \mathrm{~g} / 1.50 \mathrm{~kg}$ \\
\hline
\end{tabular}

${ }^{*}$ TE: trace elements.

biochar by using a hoe or rake. The application of PK biochar was done once a year.

2.7. Compost Application. Compost was produced from farm and kitchen wastes by following the method of Zamora and Calub [13]. Approximately $3.5 \mathrm{~kg}$ of compost was heaped on top of the mounded area of the soil. By doing this, the compost acted as mulch and also as a soil conditioner. Compost application was done every three months from the onset of the experiment.

2.8. Soil Physical Properties Determination. For two assessment years, soil samples were analyzed for bulk density, porosity, and soil texture according to the method by Edwards [15].

2.9. Soil Chemical Properties Determination. To further understand the fertility status of the soil, samples were collected with an auger at a depth of $0-15 \mathrm{~cm}$ and analyzed for its $\mathrm{pH}$, total organic carbon (TOC), loss on ignition method; total nitrogen $(\mathrm{N})$, the Kjeldahl method; $\mathrm{C} / \mathrm{N}$ ratio; available phosphorus (P), the Bray method; exchangeable potassium (K), the Double Acid method; calcium (Ca), the Double Acid method; sodium $(\mathrm{Na})$, the Double Acid method; and magnesium (Mg), the Double Acid method, according to standard procedures by Edwards [15].

2.10. Pepper Physiological Measurement. Measurements on pepper net photosynthesis rate $(A)$, leaf stomatal conductance rate $(g s)$, transpiration rate $(E)$, Normalized Difference Vegetation Index (NDVI), and leaf chlorophyll concentration were conducted before the annual harvest of pepper berries following the method of Evans and Santiago [16].

2.11. Statistical Analysis. Data were analyzed using one-way analysis of variance (ANOVA) and SPSS software (version 15) was used as the statistical software. Tukey's Honest Significance Difference (HSD) test, at $\alpha=0.05$ level of significance, was done to compare treatment means. Relationships between pepper leaf chlorophyll and soil total $\mathrm{N}$, pepper NDVI and soil total N, and pepper photosynthesis rate and soil total $\mathrm{N}$ were also determined using trend analysis. 


\section{Results and Discussion}

3.1. Soil Physical Properties. The soil bulk density and porosity of treatments under different soil amendments are presented in Table 3. In the first year (2017), bulk density for treatment FPJ showed the highest value followed by treatments FFJ incorporated with biochar and compost (FFJBC) and treatment under $12: 12: 17$ fertilization (FNPK). In the next assessment year (2018), the biochar and compost treated soils (FPJBC and FFJBC) showed lower bulk densities compared to those of FPJ and FFJ. Soil amended with 12:12:17 fertilizer (FNPK) recorded the highest bulk density. The results in Table 3 also showed that soil bulk densities and soil porosities were inversely related. The decrease in soil bulk density with biochar and compost application directly resulted in an increase in soil porosity. Soils in the 12:12:17 fertilized plot (FNPK) depicted the lowest porosity value at the end of the study. Mensah and Frimpong [17] stated that the relationship of soil bulk density and porosity is reciprocal such that whereas one increases, the other decreases.

Schulz and Glaser [18] mentioned that one of the reasons for soils exhibiting significantly low bulk densities and high porosities was the presence of organic amendments such as biochar and compost. Adugna [19] stated that compost application influences soil structure by lowering soil density due to the addition of low-density organic matter into the soil. This beneficial effect has been observed in other studies and is associated with an increase in porosity because of the interactions between organic and inorganic fractions [19]. Biochar can also play a role in lowering soil bulk density and at the same time elevating soil porosity [21]. According to Hunt et al. [22], one of the mechanisms which could be responsible for the reduction in soil bulk density following biochar application is that biochar has a lower bulk density $(<0.6 \mathrm{~g} \mathrm{~cm}-3)$ than soil $(\sim 1.25 \mathrm{~g} \mathrm{~cm}-3)$. Hence, biochar application probably reduces the density of the bulk soil through the mixing or dilution effect. International Biochar Initiative [21] also documented that biochar particles have a porosity of 70 to $90 \%$. The addition of this porous material to the soil can concomitantly increase soil porosity [23]. The mixture of fermented juices, biochar, and compost can increase meso- and macropores because of improved aggregation and stabilization of soils through the activities of soil micro- and macroorganisms [24]. Sim and Paulus [3] opined that having soils with ideal bulk density and porosity is essential for root growth and development of pepper vines as they enable plant roots extension with fewer restrictions on available nutrients and water.

3.2. Soil Chemical Properties. The effect of soil amendments for a period of two years on total organic carbon (TOC), total nitrogen $(\mathrm{N}), \mathrm{C} / \mathrm{N}$ ratio, and available phosphorus $(\mathrm{P})$ of soil grown with mature pepper vines is presented in Table 4 . The increase in soil TOC in treatments FPJBC and FFJBC were due to the addition of more carbon source through the application of biochar and compost. A study by Schulz and Glaser [18] reported that that increase in soil TOC among organic fertilizer treatments was due to the addition of carbon source through biochar and compost made of farmyard manure, root biomass, and crop residues. Furthermore, Ghasemzadeh and Jaafar [25] reported that longterm application of inorganic fertilizer may not keep TOC content sustainable in the soil. In general, biochar and compost application increase soil TOC content compared to inorganic (chemical) fertilizer and hence enhances the crop yield [22].

Irrespective of year, total $\mathrm{N}$ for soils treated with organic soil amendments (FPJ, FPJBC, FFJ, and FFJBC) were significantly lower than that of the NPK fertilized soil (FNPK) (Table 4). This result suggests that the application of NPK compound fertilizer increased soil total $\mathrm{N}$ considerably. Kumar and Swarupa [26] and Yap [27] mentioned that due to substantial amount of N from the NPK compound fertilizer that was released to the soil and therefore led to soils exhibiting high $\mathrm{N}$ availability for plant optimal growth. Paulus and Sim [3] stated that high soil total $\mathrm{N}$ in pepper farms result from the use of NPK compound chemical fertilizers. Meanwhile, Rajkovich et al. [28] documented that the low $\mathrm{N}$ might be attributed to $\mathrm{N}$ immobilization due to microbial activities that occur in soils amended with organic amendments.

The result also shows that the $\mathrm{C} / \mathrm{N}$ ratio was high in soils amended with fermented juice, biochar, and compost due to the high soil TOC and at the same time low soil total $\mathrm{N}$ of these treatments (Table 4). This was in agreement with Sanchez et al. [29] who mentioned that organic materials with high $\mathrm{C} / \mathrm{N}$ ratios will lead to a higher accumulation of carbon in comparison to nitrogen in soils. Furthermore, Suhaimee et al. [30] reported that when organic amendments such as biochar or fresh composts with high $\mathrm{C} / \mathrm{N}$ ratios were applied to soils, it will take a longer time for these organic materials to decompose because microbes need to find more nitrogen from other sources, thus the high $\mathrm{C} / \mathrm{N}$ ratios and low total $\mathrm{N}$ of soils. On the other hand, the low $\mathrm{C} / \mathrm{N}$ ratio in soils treated with chemical fertilizers alone was probably due to a low concentration of easily decomposable $\mathrm{C}$ materials and a larger quantity of $\mathrm{N}$ from the inorganic fertilizer [31]. Sharma et al. [31] added that, as the process of decomposition preceded in soils under chemical fertilization, the soil $\mathrm{C} / \mathrm{N}$ ratio decreased with the loss of $\mathrm{C}$ and conservation of $\mathrm{N}$.

Meanwhile, the high soil available P in FNPK treatment was probably due to the application of NPK fertilizer (Table 4). This was in agreement with Kumar and Swarupa [26] and Yap [27] who stated that common inorganic compound fertilizers contain a high amount of important blended nutrients including $\mathrm{P}$ which are important for plant's growth and is ready to be released into the soil. As for the high available $\mathrm{P}$ in soils under organic amendments, these results suggest that it was probably due to the actions of beneficial microbes from the fermented juices. Saied et al. [32] documented that beneficial microorganisms with the ability to solubilize nutrients such as Bacillus spp. and Aspergillus spp. are essential to the ecosystem of the soils because they can transform insoluble nutrients such as $\mathrm{P}$ into a soluble form which can be easily taken up by the plants. Talaat et al. 


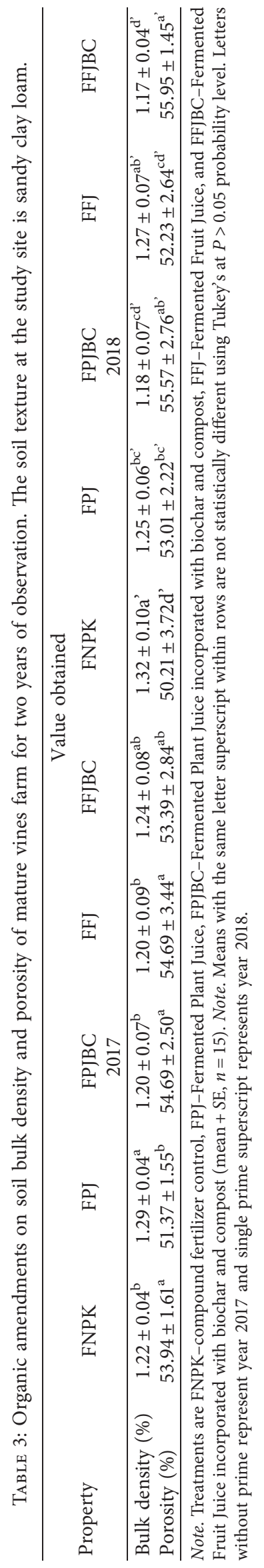




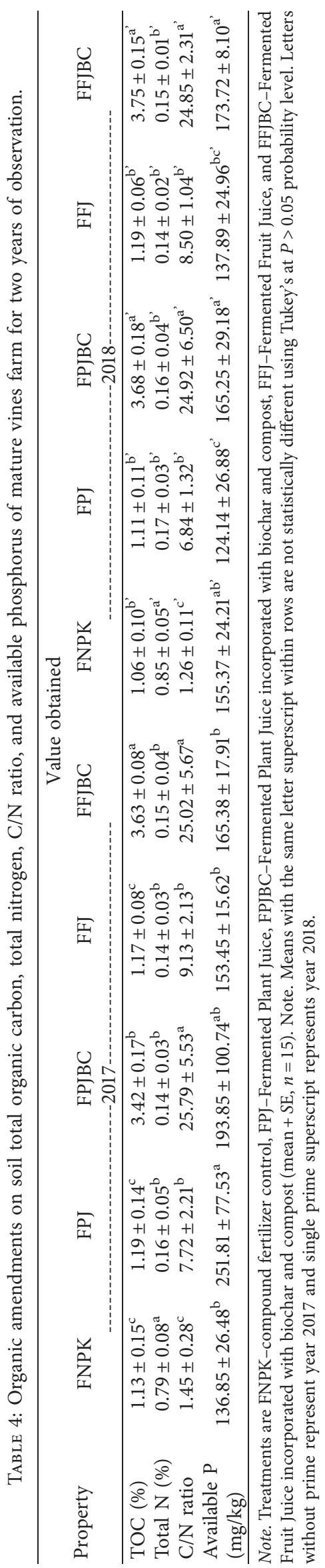


[33] mentioned that biochar addition into the soil further enhances the effectiveness of these beneficial microbes by sheltering them while the application of compost stimulates their activities which release available $\mathrm{P}$ into the soil.

The results for soil $\mathrm{pH}$, exchangeable potassium (K), calcium (Ca), sodium ( $\mathrm{Na}$ ), and Magnesium $(\mathrm{Mg})$ for two assessment periods are shown in Table 5. It was observed that soil $\mathrm{pH}$ increased in soils applied with the combined fermented juices, biochar, and compost. Agegnehu et al. [20] reported that composts have a liming effect because of their richness in alkaline or base cations such as $\mathrm{Ca}, \mathrm{Mg}, \mathrm{Na}$, and $\mathrm{K}$ which were liberated from organic matter through mineralization. Lawrinenko [23] also added that increase in soil $\mathrm{pH}$ following the application of organic amendments was due to organic anions in such amendments, and this was suggested by the concentration of excess cations over inorganic anions.

The results suggest that the application of biochar and compost together with fermented juices increased soil $\mathrm{K}$ until reaching a value which was comparable to that of the standard set by NPK fertilizer. The high amount of exchangeable $\mathrm{K}$ in treatments $\mathrm{FPJBC}$ and FFJBC can be associated with the combined interaction of beneficial microbes from fermented juices, biochar, and compost. A study from Yadav et al. [34] mentioned that when conditioning soil, it may be possible to enhance the effectiveness of beneficial microbes such as $\mathrm{K}$ solubilizers by adding biochar, or a similar material with tiny perforations, in which these microbes can house themselves and survive. Pei-Feng et al. [35] reported that composts inoculated with beneficial microbes such as $\mathrm{K}$ solubilizers significantly improve the availability of soluble $\mathrm{K}$ in soils to be taken up by plants. In addition, Talaat et al. [33] stated that improved soil $\mathrm{K}$ in soils treated with EM-inoculated composts compared with untreated composts is related to the hastened decomposition of organic compounds into plant available nutrients. Sharma et al. [31] added that EM compost is a good source of nutrients for crops, which can provide favourable conditions for the growth of crops, promoting the mobilization of insoluble nutrients and activating the beneficial microorganisms in soils.

The high Ca in soils amended with FPJBC and FFJBC treatments was due to the high Ca content of the ash materials in the biochar itself (Table 5). This finding concurred with Mensah and Frimpong [17] who documented that the presence of ash in biochar boosts the release of micronutrients such as $\mathrm{Ca}$ and $\mathrm{K}$ into the soils for crops use. The application of NPK compound fertilizers can also increase the $\mathrm{Na}$ and $\mathrm{Mg}$ content in soils as shown in Table 5. While compound fertilizers generally contain important macronutrients, namely, N, P, and K; some micronutrients such as $\mathrm{Ca}, \mathrm{Na}$, and $\mathrm{Mg}$ were blended in as well as supplementary trace elements [26, 27]. However, it was not entirely known what may have caused the slight increase of soil exchangeable $\mathrm{Na}$ and $\mathrm{Mg}$ in treatments FFJ and FFJBC. It may be due to the organic materials itself used in the making of fermented juices and composts that might contain traces of $\mathrm{Na}$ and Mg. Marcote et al. [36] opined that organic soil amendments such as microbe-based liquid fertilizers and compost containing materials that make micronutrients such as $\mathrm{Na}$ and $\mathrm{Mg}$ more available to the plants; therefore, it is nature's ultimate organic fertilizer and soil conditioner. Khaliq et al. [37] stated that most nutritious compost and liquid organic fertilizers are made from a wide variety of waste materials and therefore can make micronutrients such as $\mathrm{Na}$ and $\mathrm{Mg}$ available to the soils.

Overall, it was found that the NPK fertilized soils of the mature vines demonstrated certain soil properties which gave extremely unfavourable values at the end of the assessment period. For instance, the soil total organic carbon from farm grown with mature vines was very low when compared to other treatments. Sim and Paulus [3] reported that certain soil dynamics may have changed as mature pepper requires more nutrients for growth and yield development. In this study, the extremely unfavourable soil hardness and TOC from the mature vines farm can also be attributed to the age of the farm itself which was five years at the end of the assessment period. Paulus and Sim [3] reported that currently, continuous long-term use of chemical fertilizers on pepper vines appeared to cause soils to have a low organic matter or total carbon as well as highly acidic cations. This trend has become stronger with increasing farm duration and can reduce the life expectancy of pepper vines in the long-run if the soils are not replenished.

3.3. Pepper Physiological Characteristic. The black pepper selected physiological characteristics under NPK fertilizer and organic soil amendments are presented in Table 6. The result showed that the addition of biochar and compost to fermented juices increased leaf chlorophyll concentration of black pepper. An almost similar trend was observed for the pepper Normalized Difference Vegetation Index (NDVI). The results in this study suggest that NPK fertilization which was most commonly associated with high $\mathrm{N}$ availability in soils was not responsible for the increase of both leaf chlorophyll concentrations and NDVI of pepper. Instead, it was the application of biochar, compost, and fermented juices that have contributed to the significant leaf chlorophyll and NDVI increased. In addition to that, the total $\mathrm{N}$ of soils under soils incorporated with organic soil amendments was very low as shown previously in Table 4 .

The relationship between leaf chlorophyll concentration and soil total $\mathrm{N}$ subjected to different soil amendments is shown in Figure 2. The negative relationship between the two regardless of treatments was best described as a linear regression line with $R^{2}=0.73$. This outcome showed close inverse relations between the two factors in which leaf chlorophyll concentration decreased with increasing soil total N. Paulus and Sim [3] reported that long-term and extensive use of chemical fertilizers which contain high $\mathrm{N}$ applied around mature pepper vines appeared to have an adverse effect to the soils contributing to low nutrient exchange and water-holding capacity thus affecting leaf chlorophyll formation.

The relationship between Normalized Difference Vegetation Index (NDVI) and soil total $\mathrm{N}$ was also negatively correlated, $R^{2}=0.76$ (Figure 3 ). The relationship between the 


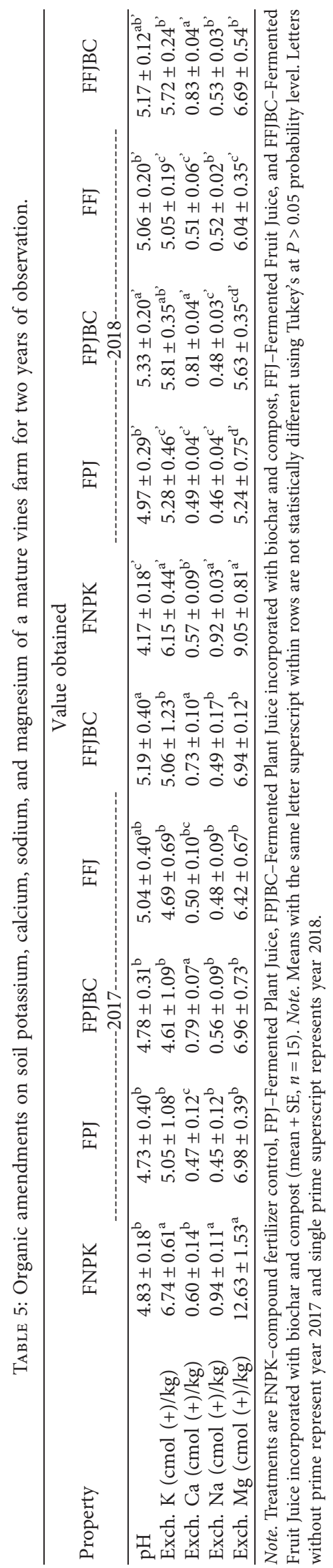




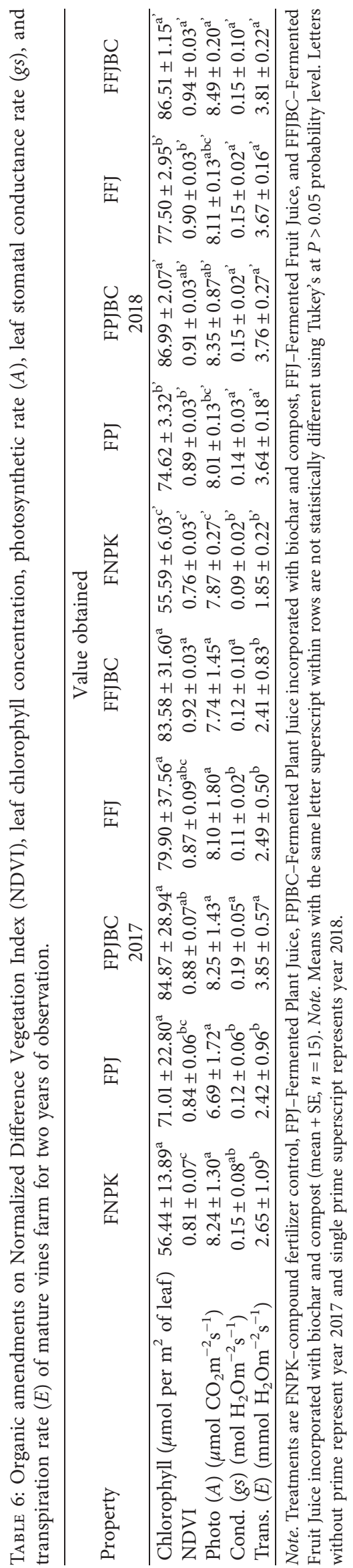




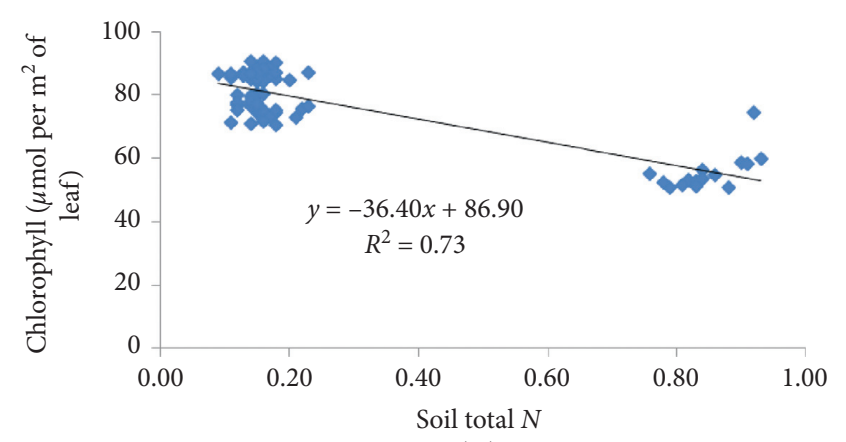

(\%)

FIGURE 2: Relationship between pepper leaf chlorophyll concentration and soil total $\mathrm{N}$ in a pepper farm grown with mature vines.

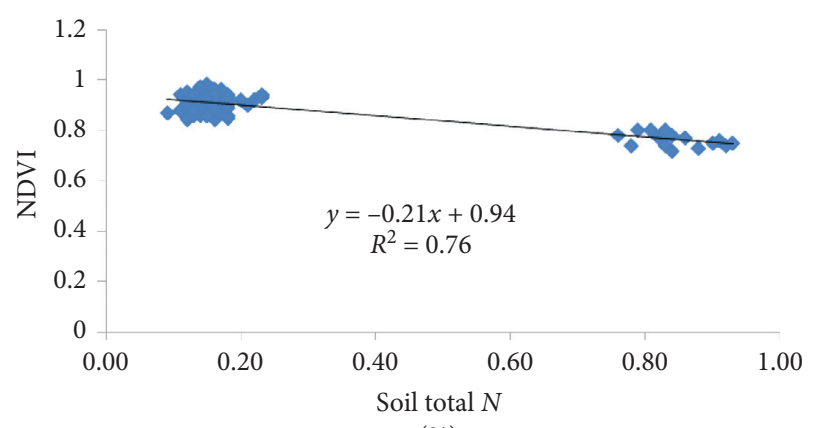

(\%)

FIgUre 3: Relationship between pepper Normalized Difference Vegetation Index (NDVI) and soil total $\mathrm{N}$ in a pepper farm grown with mature vines.

two factors regardless of treatments was best described by a linear regression line which explains a value of around $76 \%$ of the variation in NDVI. This consequence showed an inverse relationship between the two factors in which NDVI decreased with increasing soil N. Nitrogen is well known to be associated with the greenness of the leaves, where high $\mathrm{N}$ availability in soils promotes leaf growth and development, especially chloroplasts formation and accumulations of chlorophyll in them $[37,38]$. But in this study, even with high $\mathrm{N}$, content in soils will not necessarily lead to greener and healthier leaves as indicated in Figures 2 and 3.

These findings were consistent with Chen et al. [39] who reported that unfavourable environmental conditions decreased chlorophyll and NDVI of the leaves, but it was not due to less $\mathrm{N}$ content in the soil. Throughout this study, several unfavourable soil conditions were observed in soils under NPK fertilization but the conditions closely related to chlorophyll content in leaves besides soil total $\mathrm{N}$ were bulk density and porosity. This was in agreement with McGrath and Henry [40] who reported that soils with high bulk densities and low porosities tend to restrict root growth to search for water resulting in moisture stress and thus decreased leaf chlorophyll content and NDVI. Huerta-Pujol et al. [41] examined the consequences of drought stress due to hard and less permeable soils on the composition of mesophyll and bundle sheath chlorophylls of plants. The majority of chlorophyll lost from plant leaves subjected to drought stress is lost from the mesophyll cells. Huerta-Pujol et al. [41] went on to explain that the reasons for this preferential loss could be attributed to the fact that the mesophyll cells are farther removed from the vascular supply of water than the bundle sheath cells and hence develop greater cellular water deficits which lead to a greater loss of chlorophyll. McGrath and Henry [40] also mentioned that softer and porous soils enable plant roots to explore and penetrate further into the ground to obtain moisture. Because of this, plants could perform considerably better in growth and chlorophyll production even under limited $\mathrm{N}$ condition provided partitioning of $\mathrm{N}$ within the plant and efficient utilization of $\mathrm{N}$ at the cellular level [2, 42]. Furthermore, Mensah and Frimpong [17] found a correlation ( $r=0.65, P \leq 0.001)$ of TOC with soil moisture content after application of biochar and compost, corroborating that high $\mathrm{C}$ level in soils increases the water-holding capacity because of the effect of organic matter on soil aggregation. This increase provides more available water to plants, also helping with resistance to drought. Other studies done by Adugna [19] indicated that the application of compost household wastes and biochar improved the soil structural stability when compared with chemical fertilizer control. Such behavior might be the result of elevated organic matter content and important microbial activities [20]. Besides, Adugna [19] stated that aggregate and pore properties of soils are associated with specific "active" surface area influencing several storage and exchange processes in soil. The higher the specific surface area is, the more intensive interactions can occur between soil fauna, microorganisms, and root hairs under optimum conditions (e.g., sufficient humidity). As a result, a high specific surface area can create the prerequisite for an optimal soil formation [43].

The results from treatment FPJBC and FFJBC may also indicate that the application of biochar and compost increased the photosynthesis rates of pepper considerably. Although the organic fertilizer treatments have lower soil $\mathrm{N}$ when compared to that of the control as observed in Table 4, it was the improvement in soil bulk densities and porosities (Table 3), as well as TOC (Table 4) that had contributed to the photosynthesis rates increase. A study by Adugna [19] proved that plant's photosynthesis rates improved with the availability of soil moisture due to the application of soil organic amendments such as biochar and compost. Fischer and Glaser [44] stated that soil's water retentive ability correlates positively with soil total carbon content, density, and porosity. Their result showed that the compost treated soil increased soil moisture which in turn elevated photosynthesis rates by about 1.57 times than that of the NPK fertilized soils.

The relationship between pepper photosynthesis rate and soil total $\mathrm{N}$ was best described in Figure 4 by a linear regression line which explains a value of around $52 \%$ of the variation in photosynthesis rate. This showed decent relations between the two factors in which photosynthesis rates decreased slightly with increasing soil N. A similar finding by Hunt et al. [22] and Sim and Paulus [3] documented that even though soil total $\mathrm{N}$ is high, mature pepper photosynthesis rates are low when exposed to heavy and extensive usage of inorganic fertilizers, indicating soil degradation 


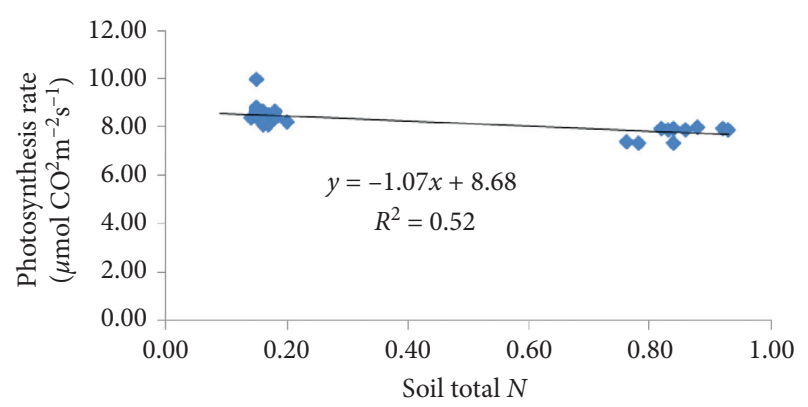

(\%)

FIGURE 4: Relationship between pepper photosynthetic rate and soil total $\mathrm{N}$ in a pepper farm grown with mature vines.

with increasing farm duration. Sim and Paulus [3] added that a degraded environment caused by excessive usage of chemicals will hinder the ability of the soil to retain nutrient and moisture thus lowering the yield of pepper vines. Fischer and Glaser [44] stated that soil organic amendments are important to ameliorate the nutrient and water retention capability of soils thus improving pepper photosynthetic rates and hence its yield.

It was found that both pepper stomatal conductance and transpiration rates in Table 6 follow an almost similar pattern. The findings suggest that prolonged application of NPK fertilizer in a mature pepper farm greatly reduced both leaf stomatal conductance and transpiration rates. Ghasemzadeh and Jaafar [25] studied that prolonged chemical fertilizers application caused soils to have low water-holding capacity due to a reduction in soil pores and increased hardness. When this happens, plants tend to respond to the low availability of soil water by reducing its stomatal opening hence decreasing conductance and transpiration rates.

It is worth to mention that farm age played a role in determining the effect of different types of fertilizers application to the soils. In this study on mature vines, the application of NPK fertilizer has an adverse effect as seen in the significant reduction of pepper leaf chlorophyll concentration, NDVI, photosynthesis rates, leaf stomatal conductance rates, and transpiration rates. Meanwhile, soils amended with fermented juices, biochar, and compost showed higher pepper physiological properties observed and were attributable to the improved nutrient and water retention capacity of the organic amendments [21]. Thus, the increase in pepper physiological characteristics due to organic amendments was in conformity with certain soil improvements which were associated with water-holding capacity such as bulk density, porosity, and TOC.

\section{Conclusion}

In this study, the application of fermented juices, biochar, and compost has significantly improved certain soil properties. Lower bulk densities and higher porosities of soil were quite evident. Favourable results for TOC, $\mathrm{C} / \mathrm{N}$ ratio, available $\mathrm{P}$, exchangeable $\mathrm{K}$, and exchangeable $\mathrm{Ca}$ were improved by the application of organic amendments. Positive results were also found in pepper leaf chlorophyll concentration, NDVI as well as photosynthetic, stomatal conductance, and transpiration rates. It was discovered that pepper leaf chlorophyll, NDVI, and photosynthesis rate were negatively correlated with soil total $\mathrm{N}$ in which these physiological traits of pepper decreased with increasing soil $\mathrm{N}$. From these findings, it can be concluded that introducing organic farming in mature black pepper cultivation can help to improve certain soil characteristics to a requirement that was better than inorganic fertilizers and at the same time provide farmers with a sustainable pepper cultivation alternative.

\section{Data Availability}

The data used to support the findings of this study are included within the article.

\section{Conflicts of Interest}

The authors declare that there are no conflicts of interest regarding the publication of this paper.

\section{Acknowledgments}

The authors acknowledge the support of Universiti Putra Malaysia and the Research and Development Division, Malaysian Pepper Board, Sarawak, Malaysia, in coming out with this manuscript. The authors would like to acknowledge the Malaysian Pepper Board for funding this research project.

\section{References}

[1] Y. Aghaye Noroozlo, M. K. Souri, and M. Delshad, "Effects of soil application of amino acids, ammonium, and nitrate on nutrient accumulation and growth characteristics of sweet basil," Communications in Soil Science and Plant Analysis, vol. 50, no. 22, pp. 2864-2872, 2019.

[2] M. K. Souri and M. Hatamian, "Aminochelates in plant nutrition: a review," Journal of Plant Nutrition, vol. 42, no. 1, pp. 67-78, 2019.

[3] A. D. Paulus and L. Sim, Pepper Production Technology in Malaysia, Malaysian Pepper Board, Kuching, Malaysia, 2011.

[4] M. Aslani and M. K. Souri, "Growth and quality of green bean (phaseolus vulgaris L.) under foliar application of organicchelate fertilizers," Open Agriculture, vol. 3, no. 1, pp. 146-154, 2018.

[5] M. Naiji and M. K. Souri, "Nutritional value and mineral concentrations of sweet basil under organic compared to chemical fertilization," Journal of Hortorum Cultus, vol. 17, no. 2, Article ID 167175, 2018.

[6] M. K. Souri and M. Bakhtiarizade, "Biostimulation effects of rosemary essential oil on growth and nutrient uptake of tomato seedlings," Scientia Horticulture, vol. 243, Article ID 472476, 2019.

[7] M. K. Souri, "Aminochelate fertilizers: the new approach to the old problem; a review," Open Agriculture, vol. 1, pp. 118-123, 2016.

[8] T. Higa, "Kyusei nature farming and environmental management through effective microorganisms. the past, present and future," 2012, http://www.infrc.or.jp/english/KNF_Data_ Base_Web/7th_Conf_KP_2.html. 
[9] P. E. Kho and Y. S. Chen, "Novel farming innovation for high production of black pepper (Piper nigrum L.) planting materials," Journal of Agricultural Science and Technology, vol. 7, pp. 301-308, 2017.

[10] Soil Survey Staff, "Keys to soil taxonomy," in SMSS Technical Monograph No. 19, Wiley, Hoboken, NJ, USA, 5th edition, 2000.

[11] S. Paramanathan, Soils of Malaysia: Their characteristics and identification, Akademi Sains Malaysia, Kuala Lumpur, Malaysia, 2000.

[12] Malaysian Pepper Board, Laporan Kajian Verifikasi Hasil, Malaysian Pepper Board, Kuching, Malaysia, 2017.

[13] O. B. Zamora and B. M. Calub, Organic Agriculture Technologies and Systems Developed and Adapted by Farmers in the Phillippines, Department of Agriculture -Bureau of Agricultural Research and University of Philippines Los BanosCollege of Agriculture, Quezon City, Phillippines, 2016.

[14] R. Wahi, A. A. Sharifah Mona, H. Sinin, and N. Zainab, "Biochar production from agricultural wastes via low-temperature microwave carbonization," in Proceeding of the 2015 IEEE International RF and Microwave Conference (RFM 2015), Riverside Majestic Hotel, Kuching, Malasyia, December 2015.

[15] A. C. Edwards, "Soil sampling and sample preparation," in Trace Elements in Soil, P. Hooda, Ed., Wiley \& Blackwell Publishing Ltd, Haboken, NJ, USA, 2010.

[16] J. R. Evans and L. S. Santiago, "PrometheusWiki gold leaf protocol: gas exchange using LI-COR 6400," Functional Plant Biology, vol. 2014, no. 41, pp. 223-226, 2014.

[17] A. K. Mensah and K. A. Frimpong, "Biochar and/or compost applications improve soil properties, growth, and yield of maize grown in acidic rainforest and coastal savannah soils in Ghana," International Journal of Agronomy, vol. 2018, Article ID 6837404, 8 pages, 2018.

[18] H. Schulz and B. Glaser, "Effects of biochar compared to organic and inorganic fertilizers on soil quality and plant growth in a greenhouse experiment," Journal of Plant Nutrition and Soil Science, vol. 175, no. 3, pp. 410-422, 2012.

[19] G. Adugna, "A review on impact of compost on soil properties, water use and crop productivity," Academic Research Journal of Agricultural Science and Research, vol. 4, no. 3, pp. 93-104, 2016.

[20] G. Agegnehu, P. N. Nelson, and M. I. Bird, "Crop yield, plant nutrient uptake and soil physicochemical properties under organic soil amendments and nitrogen fertilization on Nitisols," Soil and Tillage Research, vol. 160, pp. 1-13, 2016.

[21] International Biochar Initiative, standardized definition and product testing guidelines for biochar that is used in soil. ibiSTD-01, 2012.

[22] J. Hunt, M. DuPonte, D. Sato, and A. Kawabata, "The basics of biochar: a natural soil amendment," Soil and Crop Management, vol. 30, pp. 1-6, 2010.

[23] M. Lawrinenko, Anion Exchange Capacity of Biochar, Master of Science Thesis, Iowa State University, Ames, Iowa, 2014.

[24] P. Partanen, J. Hultman, L. Paulin, P. Auvinen, and M. Romantschuk, "Bacterial diversity at different stages of the composting process," BMC Microbiology, vol. 10, no. 1, p. 94, 2010.

[25] A. Ghasemzadeh and H. Jaafar, "Effect of $\mathrm{CO}_{2}$ enrichment on synthesis of some primary and secondary metabolites in Ginger (Zingiber officinale Roscoe)," International Journal of Molecular Sciences, vol. 12, no. 2, pp. 1101-1114, 2011.

[26] T. S. S. Kumar and P. U. Swarupa, "Cultivation practices of black pepper in India-a Review," International Journal of
Innovative Research In Management Studies (IJIRMS), vol. 2, no. 5, pp. 21-27, 2017.

[27] C. A. Yap, "Determination of nutrient uptake characteristics of black pepper (Piper nigrum L.)," Journal of Agricultural Science and Technology, vol. 6, pp. 86-89, 2012.

[28] S. Rajkovich, A. Enders, K. Hanley, C. Hyland, A. R. Zimmerman, and J. Lehmann, "Corn growth and nitrogen nutrition after additions of biochars with varying properties to a temperate soil," Biology and Fertility of Soils, vol. 48, no. 3, pp. 271-284, 2011.

[29] J. Sanchez, T. Willson, K. Kizilkaya, E. Parker, and R. Harwood, "Enhancing the mineralizable nitrogen pool through substrate diversity in long term cropping systems," Soil Science Society of America Journal, vol. 65, pp. 1442-1447, 2011.

[30] S. Suhaimee, I. Z. Ibrahim, and M. A. M. Abdul Wahab, Organic Agriculture in Malaysia, FFTC Agricultural Policy Articles: Production Policy, Taipei, Taiwan, 2016.

[31] A. Sharma, T. N. Saha, A. Arora, R. Shah, and L. Nain, "Efficient microorganism compost benefits plant growth and improves soil health in Calendula and Marigold," Horticultural Plant Journal, vol. 3, no. 2, pp. 67-72, 2017.

[32] A. Saeid, E. Prochownik, and J. Dobrowolska-Iwanek, "Phosphorus solubilization by Bacillus species," Molecules, vol. 23, no. 11, p. 2897, 2018.

[33] N. B. Talaat, A. E. Ghoniem, M. T. Abdelhamid, and B. T. Shawky, "Effective microorganisms improve growth performance, alter nutrients acquisition and induce compatible solutes accumulation in common bean (Phaseolus vulgaris L.) plants subjected to salinity stress," Plant Growth Regulation, vol. 75, no. 1, pp. 281-295, 2015.

[34] A. N. Yadav, R. Kumar, S. Kumar et al., "Beneficial microbiomes: biodiversity and potential biotechnological applications for sustainable agriculture and human health," Journal of Applied Biology \& Biotechnology, vol. 5, no. 6, pp. 45-57, 2017.

[35] S. Pei-Feng, F. Wei-Ta, S. Li-Ying, W. Jyuan-Yu, F. Shih-Feng, and C. Jui-Yu, "Indole-3-Acetic Acid-producing yeasts in the phyllosphere of the carnivorous plant Drosera indica L," PLoS One, vol. 9, no. 12, Article ID e114196, 2014.

[36] I. Marcote, T. Hernández, C. Garc1'a, and A. Polo, "Influence of one or two successive annual applications of organic fertilizers on the enzyme activity of a soil under barley cultivation," Bioresource Technology, vol. 79, pp. 147-154, 2011.

[37] A. Khaliq, M. K. Abbasi, and T. Hussain, "Effects of integrated use of organic and inorganic nutrient sources with effective microorganisms (EM) on seed cotton yield in Pakistan," Bioresource Technology, vol. 97, no. 8, pp. 967-972, 2016.

[38] K. Shanmugapriya, P. S. Saravana, P. Harsha, S. Peer Mohammed, and W. Binnie, "Antioxidant potential of pepper (Piper nigrum Linn.) leaves and its antimicrobial potential against some pathogenic microbes," Indian Journal of Natural Products and Resources, vol. 3, no. 4, pp. 570-577, 2012.

[39] Z. Chen, H. Wang, X. Liu, D. Lu, and J. Zhou, "The fates of $15 \mathrm{~N}$-labeled fertilizer in a wheat-soil system as influenced by fertilization practice in a loamy soil," Scientific Reports, vol. 6, Article ID 34754, 2016.

[40] D. McGrath and J. Henry, "Organic amendments decrease bulk density and improve tree establishment and growth in roadside plantings," Urban Forestry \& Urban Greening, vol. 20, pp. 120-127, 2016.

[41] O. Huerta-Pujol, M. Soliva, F. X. Martínez-Farré, J. Valero, and M. López, "Bulk density determination as a simple and 
complementary tool in composting process control," Bioresource Technology, vol. 101, no. 3, pp. 995-1001, 2010.

[42] M. J. Hawkesford and S. Griffiths, "Exploiting genetic variation in nitrogen use efficiency for cereal crop improvement," in Current Opinion in Plant Biology, C. Kohler and D. Wagner, Eds., pp. 35-42, Elsevier, Amsterdam, Netherlands, 2019.

[43] F. Amlinger, S. Peyr, J. Geszti, P. Dreher, W. Karlheinz, and S. Nortcliff, Beneficial Effects of Compost Application on Fertility and Productivity of Soils, Literature Study, Federal Ministry for Agriculture and Forestry, Environment and Water Management, Veinna Austria, 2007.

[44] D. Fischer and B. Glaser, "Synergisms between compost and biochar for sustainable soil amelioration, management of organic Waste," in In Tech, S. E. Kumar, Ed., pp. 167-198, Shanghai University, Shanghai, China, 2012. 